\title{
Life Cycle Inventory Energy Consumption and Emissions for Biodiesel versus Petroleum Diesel Fueled Construction Vehicles
}

\author{
Shih-Hao Pang, H. Christopher Frey*, William J. Rasdorf \\ Department of Civil, Construction, and Environmental Engineering \\ North Carolina State University \\ Campus Box 7908 \\ Raleigh, NC 27695-7908
}

\begin{abstract}
Substitution of soy-based biodiesel fuels for petroleum diesel will alter life cycle emissions for construction vehicles. A life cycle inventory was used to estimate fuel cycle energy consumption and emissions of selected pollutants and greenhouse gases. Real-world measurements using a portable emission measurement system (PEMS) were made for five backhoes, four front-end loaders, and six motor graders on both fuels from which fuel consumption and tailpipe emission factors of $\mathrm{CO}, \mathrm{HC}, \mathrm{NO}_{\mathrm{x}}$, and $\mathrm{PM}$ were estimated. Life cycle fossil energy reductions are estimated at $9 \%$ for B20 and $42 \%$ for B100 versus petroleum diesel based on the current national energy mix. Fuel cycle emissions will contribute a larger share of total life cycle emissions as new engines enter the in-use fleet. The average differences in life cycle emissions for B20 versus diesel are: $3.5 \%$ higher for $\mathrm{NO}_{\mathrm{x}} ; 11.8 \%$ lower for $\mathrm{PM}, 1.6 \%$ higher for $\mathrm{HC}$, and $4.1 \%$ lower for CO. Local urban tailpipe emissions are estimated to be $24 \%$ lower for $\mathrm{HC}, 20 \%$ lower for CO, $17 \%$ lower for $\mathrm{PM}$, and $0.9 \%$ lower for $\mathrm{NO}_{\mathrm{x}}$. Thus, there are environmental trade-offs such as for rural versus urban areas. The key sources of uncertainty in the B20 LCI are vehicle emission factors.
\end{abstract}

\section{INTRODUCTION}

Life cycle inventories (LCI) are used to compare fuels, taking into account energy consumption and emissions for fuel production and use. LCI methods include process flow diagrams, matrix representations of product systems, and input-output methods (8-11). Process flow diagrams are the most commonly used. An example is the "Greenhouse Gases, Regulated Emissions, and Energy use in Transportation" (GREET) model of Argonne National Laboratory (13). Over half of U.S. biodiesel is made from soybean oil ("soyoil"). Biodiesel can be used in a diesel engine without major modifications (1). Biodiesel is typically blended in a 20:80 percent volume ratio with petroleum diesel (PD), known as B20. B20 has been shown to have lower tailpipe emissions of particulate matter (PM), carbon monoxide $(\mathrm{CO})$, and hydrocarbons (HC) for years. Nitrogen oxides $\left(\mathrm{NO}_{\mathrm{x}}\right)$ have been a focus of policy debate as to whether biodiesel can create lower $\mathrm{NO}_{\mathrm{x}}$ emissions. Both engine dynamometer tests conducted by the United States Environmental Protectection Agency (USEPA) and chassis dynamometer tests conducted by the National Renewable Energy Laboratory (NREL) have shown a slight increase of $\mathrm{NO}_{\mathrm{x}}$ emissions from tailpipes when using B20 (2, 3). However, real-world in-use measurements using a portable emission measurement system (PEMS) have shown an average decrease in vehicle tailpipe emissions of $\mathrm{NO}_{\mathrm{x}}, \mathrm{PM}, \mathrm{CO}$, and $\mathrm{HC}$ when comparing B20 and PD over 35 onroad and nonroad heavy duty diesel vehicles used in the construction industry (4-7). Even though tailpipe emissions 
contribute significantly to life cycle emissions, none of the previous life cycle studies apply in-use data for the LCI $(10,13,17,18)$.

Production of soy-based B100 blendstock includes: soybean farming, soyoil extraction, and biodiesel production. Most U.S. soyoil extraction plants use a solvent to remove the oil from the soybeans (17). These plants are the most significant source of biodiesel life cycle HC emissions (13). In November 2004, EPA promulgated New Source Performance Standards (NSPS) applicable to the solvent extraction process (18). The standards require reduction of emissions of air toxics and volatile organic compounds (VOCs) from vegetable oil production facilities. Previous life cycle studies have not considered the EPA new emission standards applicable to soyoil plants as is done herein $(10,13,17,18)$.

An updated and modified LCI is developed here in order to improve the evaluation of the benefits of biodiesel and to assess the tailpipe emissions of selected types of construction vehicles. The key improvements include: update of combustion emission factors based on 2006 US national average emission rates; comparison of Pre-NSPS and NSPS-compliant soyoil plants; the use of PEMS data for real-world tailpipe emission factors; and comparisons based on 15 nonroad diesel vehicles. The key research questions addressed here are: (1) What are the best estimates of energy use and emissions associated with fuel production and tailpipe emissions for PD and B20; (2) What is the uncertainty in these estimates; (3) What are the key sources of uncertainty; and (4) What are the emissions implications of the use of biodiesel fuel for nonroad construction vehicles?

\section{METHODOLOGY}

The key elements of the methodology include:

- Defining the system boundaries of the LCI;

- Quantifying the fuel life cycles of PD and biodiesel;

- Quantifying tailpipe emissions of backhoes, front-end loaders, and motor graders; and

- Applying the LCI model to quantify energy use, emissions, and uncertainties.

\section{System Boundary}

An LCI involves quantification of energy use, raw material requirements, and air pollutant emission throughout the life cycle of a product. The generally accepted system components for PD production include crude oil recovery, crude oil transport, crude oil refining, diesel transport, and vehicle operation. The generally accepted system components for biodiesel production include soybean agriculture, soyoil production, soyoil transport, biodiesel production, biodiesel transport, and vehicle operation. Fossil energy is consumed for operating farm equipment and for manufacturing, procuring, and distributing fertilizers, herbicides, and pesticides (13, 19-21). Most soybeans are transported to an oil production plant within 75 miles of the farming area (10). The average distance in the U.S. from a soyoil production plant to a biodiesel plant has been reported as 600 miles (13). At a biodiesel plant, biodiesel is produced by transesterification which converts soyoil to biodiesel. More recently new plants have been built reflecting the possibility of shorter haul distances. We investigated an alternative 40 mile distance and found that in either distance 
the energy use from transport itself was $0.58 \%$ or less making this transport segment a negligible contributor to LCI energy consumption.

\section{Fuel Life Cycle}

The fuel cycle energy use and air emissions were calculated based on GREET (20), run in Microsoft EXCEL, for which the following information was updated:

- Combustion source emission factors (e.g., for coal-fired utility and industrial boilers based on 2006 US national average emission rates) and emission factors for Pre-NSPS and NSPS-compliant soyoil plants;

- Vehicle tailpipe emission rates (based on real-world measurement data for PD and B20); and

- Biogenic $\mathrm{HC}$ emissions during soybean farming (estimated based on measurements of air-surface exchange rates of HC compounds (22)).

Emission factors for each combustion source were updated based on U.S. national average emission rates $(9,23)$ :

$$
\mathrm{EF}_{\mathrm{i}, \mathrm{j}, \mathrm{k}}=\frac{\mathrm{E}_{\mathrm{i}, \mathrm{j}, \mathrm{k}}}{\mathrm{EC}_{\mathrm{j}, \mathrm{k}}}
$$

where

$$
\begin{array}{ll}
E F_{i, j, k} & =\text { Emission factor of pollutant } i, \text { fuel } j, \text { and combustion technology } k\left(\frac{l b}{10^{6} B t u}\right) \\
E_{i, j, k} & =\text { U.S. total emissions for pollutant } i \text {, fuel } j, \text { and combustion technology } k(l b) \\
E C_{j, k} & =\text { U.S. total energy consumption of fuel } j \text { for combustion technology } k\left(10^{6} \text { Btu }\right)
\end{array}
$$

Fuel life cycle emissions were estimated based on energy consumption and emission factors for each combustion technology:

$$
E M_{i, l}=E F_{i, j, k} \times E C_{j, k, l}
$$

where

$E M_{i, l} \quad=$ Emissions of pollutant $i$ and stage $l$ (g/gallon fuel throughput)

$E F_{i, j, k}=$ Emission factor of pollutant $i$, fuel $j$ and combustion technology $k(\mathrm{~g} / \mathrm{Btu})$

$E C_{j, k, l}=$ Energy consumption of fuel $j$, combustion technology $k$ and stage $l$ (Btu/gallon fuel throughput)

Emissions during the transport of raw materials and fuel products were estimated based upon distances traveled and gram-per-mile emission factors in GREET (24).

\section{Vehicle Tailpipe Emissions}

Tailpipe emissions data were collected for five backhoes, four front-end loaders, and six motor graders using a PEMS. Each vehicle was tested once on PD and once on B20. The vehicle characteristics are given in Table 1.

The PEMS used in this study was the OEM-2100 "Montana" system manufactured by Clean Air Technologies International, Inc. (25). This system consists of: (a) two parallel five-gas analyzers; (b) a PM measurement system; (c) an engine sensor array for measuring engine RPM, manifold absolute pressure, and intake air temperature; (d) a global position system (GPS); and (e) an 
on-board computer. PM measurements are based on a light scattering method, which is analogous to opacity.

The PEMS light scattering-based PM measurement is adequate for relative comparisons between $\mathrm{PD}$ and B20. However, in order to estimate the absolute value of PM emission factors, the NONROAD model was used to estimate PM emission factors based on PD (10). The PM emission factors for B20 $\left(E F_{B 20}\right)$ are estimated as:

$$
E F_{B 20}=E F_{P D} \times \frac{\text { Opacity }_{B 20}}{\text { Opacity }_{P D}}
$$

where

$E F_{B 20} \quad=\quad \mathrm{PM}$ emission rate for $\mathrm{B} 20$ (g/gallon);

$E F_{P D} \quad=\quad \mathrm{PM}$ emission rate for $\mathrm{PD}$ (g/gallon);

Opacity $_{B 20}=$ Opacity for B20 based on PEMS measurements; and

Opacity $_{P D}=$ Opacity for PD based on PEMS measurements;

\section{Study Design}

The fuel life cycle scenarios include: baseline PD; B20 produced from a Pre-NSPS soyoil plant; and B20 produced from an NSPS soyoil plant. The vehicle emissions scenarios include: baseline PD in-use measurement data based on PEMS (4, 7); B20 in-use measurement data based on PEMS $(4,7)$; estimated B20 vehicle emissions based on EPA's engine dynamometer data (2); and estimated B20 vehicle emissions based on NREL's chassis dynamometer data (3). Because there are several possible configurations, seven scenarios were used for LCI analysis, as listed in Table 2. The baseline scenario is for PD with in-use PEMS measurement data for tailpipe emissions. For the B20 LCI, each vehicle has two fuel cycle scenarios and three vehicle emissions scenarios, which include 6 scenarios in total. In order to represent real-world activities, two or three duty cycles were observed for each type of vehicle during PEMS measurements. For example, backhoe loaders have three different duty cycles: (1) load a truck; (2) material handling; and (3) mass excavation. The tailpipe emissions used in the LCI model were averaged over those duty cycles.

\section{Uncertainty Analysis}

Uncertainty in life cycle assessment arises from a lack of knowledge regarding the true value of any one or more of the inputs $(23,24)$. Monte Carlo simulation was used to quantify uncertainty in LCI models $(25,26)$. The GREET model includes default probability distributions to account for uncertainty of each input in the fuel life cycle (27). Probability distributions of uncertainty in combustion emission factors were assigned based upon previous studies and professional judgment. As an example for coal-fired power plants, the $95 \%$ range of uncertainty in $\mathrm{NO}_{\mathrm{x}}$ emission factors is $\pm 25 \%$ of the mean (28). As another example, the range of uncertainty relative to the mean for AP-42 emission factors for natural-gas-fired engines are $-34 \%$ to $+47 \%$ for $\mathrm{NO}_{\mathrm{x}}$ and $-33 \%$ to $+37 \%$ for $\mathrm{HC}$, respectively (32). For other combustion sources, the relative uncertainty ranges are judged to be $\pm 40 \%$ for $\mathrm{NO}_{\mathrm{x}}, \pm 35 \%$ for $\mathrm{HC}, \pm 30 \%$ for $\mathrm{CO}$, and $\pm 30 \%$ for $\mathrm{PM}$. For vehicle tailpipe emissions, the relative uncertainty ranges are $\pm 3 \%$ for $\mathrm{HC}, \pm 8 \%$ for $\mathrm{CO}$, $\pm 3 \%$ for $\mathrm{NO}, \pm 2 \%$ for $\mathrm{CO}_{2}$, and $\pm 5 \%$ for PM, based on the precision of the PEMS data. 
Crystal Ball ${ }^{\mathrm{TM}}$, an add-in software to EXCEL ${ }^{\mathrm{TM}}$, was used to quantify uncertainty in the inputs and estimate uncertainty in the outputs of the LCI based on Monte Carlo simulation. Examples of selected key input assumptions are given in Table 3.

\section{RESULTS}

The life cycle fossil energy consumption and emissions are quantified. The key sources of uncertainty are identified by Monte Carlo simulation. The spatial distribution of biodiesel life cycle emissions is evaluated to help assess the effect on urban and rural emissions.

\section{Petroleum Diesel and Biodiesel Life Cycle Inventory}

An example of the results for the estimated life cycle energy consumption and emissions is shown in Figure 1 based on a Front-End Loader 1 (FL1 in Table 1) and on Scenarios 1, 2, and 5. For PD, the fuel cycle energy use contributes approximately $16 \%$ of the total life cycle energy consumption. While the operation of the vehicle itself consumes more energy than does the fuel cycle for producing the fuel, the amount of energy consumed during the fuel cycle is far from negligible. Crude oil refining contributes most to the fuel cycle energy consumption and to $\mathrm{PM}, \mathrm{CO}$, and $\mathrm{CO}_{2}$ emissions. The results are similar for other vehicles. Sheehan et al (10) concluded that life cycle primary energy (or total energy) for PD and BD are similar because in their model they do not use an internal commodity flow loop system. Thus they under-estimated the energy consumption in the overall LCI (11). The results shown in this paper included loop calculations among different process energy, such as electricity, oil, etc. Thus, the BD LCI primary energy is higher than in Sheehan's study.

A NSPS-compliant soyoil plant consumes less energy than Pre-NSPS plants due to improved efficiency. However, the difference in total LCI energy consumption between NSPS and Pre-NSPS soyoil plants is less than 2\%. The average differences between B20 versus PD LCI emissions per gallon of diesel equivalent are shown in Table 4. When comparing all six B20 scenarios versus PD, the average and range of difference in life cycle emissions are: $3.5 \%(+1.7$ to $+5.2 \%$ ) higher for $\mathrm{NO}_{\mathrm{x}} ; 11.8 \%$ (7.8 to $14.3 \%$ ) lower for $\mathrm{PM},+1.6 \%$ (9.9\% to $\left.16.3 \%\right)$ higher for $\mathrm{HC}$, and $4.1 \%(-3.3 \%$ to $+10.7 \%)$ lower for $\mathrm{CO}$.

Even though tailpipe emissions are the largest contribution to $\mathrm{LCI} \mathrm{NO}_{\mathrm{x}}$ emissions; for some scenarios, tailpipe $\mathrm{NO}_{\mathrm{x}}$ emissions decrease when using B20. Meanwhile high $\mathrm{NO}_{\mathrm{x}}$ emissions from the biodiesel fuel cycle result in overall LCI NOx increases. Hence, life cycle $\mathrm{NO}_{\mathrm{x}}$ emissions are slightly higher in all cases.

Life cycle PM emissions are lower. $\mathrm{HC}$ and $\mathrm{CO}$ emissions differences depend on the scenario. Life cycle $\mathrm{HC}$ emissions are higher for Scenario 2, 3, and 4, because of high $\mathrm{HC}$ emissions from Pre-NSPS soyoil plants. In general, LCI emissions of HC and CO are lower if NSPS-compliant soyoil plants are used.

EPA has set progressively more stringent Tier 1 to Tier 4 emission standards for engines used in construction vehicles. As the tailpipe emissions are reduced from newer engines (e.g. Tier 2 or 
Tier 3), vehicle emissions will contribute less to the LCI, as shown in Table 5. Thus, over time, more attention should be focused on reducing fuel cycle as well as tailpipe emissions.

The distribution between fossil and renewable energy consumption for one diesel equivalent gallon of fuel is shown in Figure 2. The total energy consumed to produce B20 or B100 is higher than for PD, but less fossil energy is used. The fossil energy contribution to the B20 life cycle is $83 \%$, versus $37 \%$ for pure B100 blend stock. The use of B20 instead of PD will reduce fossil energy consumption and $\mathrm{CO}_{2}$ emissions by $9 \%$ based on NSPS soyoil plants. The reduction for $\mathrm{B} 100$ is $42 \%$. These percentages could increase if the share of non-fossil energy resources in power generation and transportation increase.

\section{Uncertainty}

The average, and 95 percent probability range, of the difference in LCI emissions for B20 versus PD over the 15 measured nonroad vehicles is shown in Table 4. Even in the face of uncertainty, LCI $\mathrm{NO}_{\mathrm{x}}$ emissions increase slightly even for scenarios in which tailpipe emissions decrease. For PM, the B20 LCI emissions are approximately 11.8 percent lower, with a robust finding that there is a decrease even when uncertainty is considered. For HC, the estimated increase in LCI emissions for Pre-NSPS soyoil plants is robust to uncertainty, whereas the estimated decrease for NSPS-compliant plants is robust except if the chassis dynamometer emissions data are assumed to be representative. For CO, the LCI emissions are lower for B20 except if EPA emission factor data are used. Overall, for an NSPS-compliant soyoil plant, there are small net increases in LCI $\mathrm{NO}_{\mathrm{x}}$ emissions and average decreases of varying proportions for PM, HC, and CO.

Since vehicle tailpipe emissions contribute to most of the life cycle emissions for B20 and PD, vehicle tailpipe emissions are the most sensitive inputs to the life cycle $\mathrm{HC}, \mathrm{CO}, \mathrm{NO}_{\mathrm{x}}$, and $\mathrm{PM}$ emissions. The rank correlation of the uncertainty in the LCI emissions to the vehicle tailpipe emission uncertainty ranges from $59 \%$ to $97 \%$ percent, depending on the vehicle, pollutant, and scenario.

For $\mathrm{CO}_{2}$ emissions and energy consumption, the uncertainty in the B20 and PD LCI was dominated by diesel refining efficiency with average rank correlation of $72 \%$ and $79 \%$, respectively.

\section{Spatial Distribution of Biodiesel Life Cycle Inventory Emissions}

Most of the current soybean yield in the U.S. is located in Iowa, Illinois, Minnesota, and Indiana (30). The spatial distribution of soybean yield, biodiesel plants, and ozone non-attainment areas are shown in Figure 3. Biodiesel fuel production occurs mostly in Midwest states and ozone non-attainment areas are located mostly in California or the Northeast. Fuel cycle emissions most frequently occur in rural air basin, whereas tailpipe emissions most frequently occur in urban areas. Figure 4 differentiates the portion of $\mathrm{HC}, \mathrm{CO}, \mathrm{NO}_{\mathrm{x}}$, and $\mathrm{PM}$ emissions that would typically occur in urban areas, many of which are in non-attainment for ozone. On average for all tested vehicles, the B20 local urban emissions from local fuel transport and vehicle tailpipe emissions are $24.3 \%$ 
lower for $\mathrm{HC}, 20.2 \%$ lower for CO, $16.9 \%$ lower for PM and $0.9 \%$ lower for $\mathrm{NO}_{\mathrm{x}}$ compared to PD local emissions, based on NCSU data.

The largest portion of biodiesel fuel cycle HC emissions are from soyoil plants. The new NSPS standard is expected to significantly reduce these $\mathrm{HC}$ emissions. If biodiesel fuel production occurs in the same airsheds as tailpipe emissions, local urban $\mathrm{HC}, \mathrm{CO}$, and PM emissions would be decreased, but there may be an increase or a decrease in $\mathrm{NO}_{\mathrm{x}}$ depending on vehicle tailpipe $\mathrm{NO}_{\mathrm{x}}$ emissions. The air quality benefits of using biodiesel will depend on the geographic locations of the fuel production and of the vehicles consuming the fuel and on prevailing baseline air quality conditions. It is likely that the reduction in tailpipe emissions from use of B20 will occur in airsheds where air quality is a significant problem, whereas the emissions associated with the fuel cycle may occur in rural areas where air quality (e.g., ozone, PM) problems may be less pressing. However, highly localized air quality problems in rural area can be severe in some cases. Biodiesel is a promising alternative to diesel, but there are environmental trade-offs. Nonetheless, soy-based B20 offers promising environmental benefits in terms of reduced tailpipe emissions as well as reductions in fuel cycle emissions of selected pollutants. Further studies are needed to improve confidence in vehicle emission factors, which were a key source of uncertainty in LCI emissions, are needed. Further study to characterize the speciation of HC and PM will also be useful.

\section{ACKNOWLEDGEMENTS}

This material is based upon work supported by the National Science Foundation under Grant No. 0327731. Any opinions, findings, and conclusions or recommendations expressed in this material are those of the authors and do not necessarily reflect the views of the NSF. Dr. Jon Van Gerpen, Dr. Carl J Bern, Dr. Dev Shrestha, Dr. Larry Johnson, Dr. Alex Hobbs, Mr. Jim Wilder, Mr. Andy Aden, Mr. Vince Vavpot, and Mr. Bev Thessen provided useful information and suggestions for this study.

\section{SUPPORTING INFORMATION AVAILABLE}

Text, tables, and figures are available pertaining to: review of previous life cycle models and applications; detailed method of calculating energy consumption and emissions; point estimate and uncertainty input assumptions, PD and biodiesel LCI results; data on emissions from existing and new soyoil plants, and results of uncertainty analysis. This material is available free of charge via the Internet at http://pubs.acs.org.

\section{REFERENCES}

1. Duffield, J., Shapouri, H., Graboski, M., McCormick, R., Wilson R. (1998), "U.S. Biodiesel Development: New Markets for Conventional and Genetically Modified Agricultural Fats and Oils," Economic Research Service, U.S. Department of Agriculture, Washington D.C.

2. EPA (2002), "A Comprehensive Analysis of Biodiesel Impacts on Exhaust Emissions," EPA 420-P-02-001, U.S. Environmental Protection Agency, Washington D.C. 
3. McCormick, R. L., Williams A., Ireland J., Brimhall M., Hayes R. R. (2006), "Effects of Biodiesel Blends on Vehicle Emissions," NREL/MP-540-40554, National Renewable Energy Laboratory, Boulder, CO, October.

4. Frey, H. C., Rasdorf, W., Kim, K., Pang, S. H., Lewis, P., "Comparison of Real-World Emissions of Backhoes, Front-End Loaders and Motor Graders for B20 Biodiesel vs. Petroleum Diesel for Selected Engine Tiers," Transportation Research Record, accepted February 29, 2008 (in press).

5. Frey, H. C., Kim K. (2006), "Comparison of Real-World Fuel Use and Emissions for Dump Trucks Fueled with B20 Biodiesel Versus Petroleum Diesel," Transportation Research Record, 1987:110-117.

6. Frey, H. C., Kim, K. (2005), "Operational Evaluation of Emissions and Fuel Use of B20 Versus Diesel Fueled Dump Trucks," FHWY/NC/2005-07, Prepared by North Carolina State University for North Carolina Department of Transportation, Raleigh, NC.

7. Frey, H. C., Rasdorf, W., Kim, K., Pang, S., Lewis, P., Abolhasani, S., "Real-World Duty Cycles and Utilization for Construction Equipment in North Carolina," HWY-2006-08, Prepared by North Carolina State University for North Carolina Department of Transportation, Raleigh, NC, January 2008.

8. Fava, J. A., Denison, R., Jones, B., Curran, M. A., Vigon, B., Selke, S., Barnum J. (1991), "A Technical Framework for Life-Cycle Assessments," Society of Environmental Toxicology and Chemistry and SETAC Foundation for Environmental Education, Washington, DC.

9. MacLean, H. L., Lave, L. B. (2003), "Evaluating Automobile Fuel/Propulsion System Technologies," Progress in Energy and Combustion Science, 29(1): 1-69.

10. Sheehan, J., Camobreco, V., Duffield, J., Graboski, M., Shapouri, H. (1998), "Life Cycle Inventory of Biodiesel and Petroleum Diesel for Use in an Urban Bus," NREL/SR-580-24089, Prepared by the National Renewable Energy Laboratory for the U.S. Department of Agriculture and the U.S. Department of Energy, Golden, CO.

11. Suh S., Huppes, G. (2005), "Methods for Life Cycle Inventory of a Product," Journal of Cleaner Production, 13(7): 687-697.

12. Hill, J., Nelson, E., Tilman, D., Polansky, S. and Tiffany, D., (2006), "Environmental, Economic, and Energetic Costs and Benefits of Biodiesel and Ethanol biofuels. Proceedings of the National Academy of Sciences, 103, 11206-11210.

13. Huo, H., Wang, M., Bloyd, C., Putsche, V., (2008), "Life-Cycle Assessment of Energy and Greenhouse Gas Effects of Soybean-Derived Biodiesel and Renewable Fuels," Argonne National Laboratory ANL/ESD/08-2, March.

14. Erickson, D. R., Ed. (1995), "Practical Handbook of Soybean Processing and Utilization," AOCS Press, Champaign, IL and the United Soybean Board, St. Louis, MO, Chapter 5-6.

15. EPA (2004), "National Emission Standards for Hazardous Air Pollutants: Solvent Extraction for Vegetable Oil Production - Federal Register," 40 CFR Part 63, Vol. 69, No. 169, U.S. Environmental Protection Agency, Washington D.C.

16. EIT ( 2005), "Petroleum Supply Annual 2004-Volume 1," U.S. Energy Information Administration, DOE/EIA-0340(04)/1, Washington, D.C.

17. Wang, M. Q. (1999), “GREET 1.5 - Transportation Fuel-Cycle Model, Volume 1: Methodology, Development, Use, and Results," ANL/ESD-39, Argonne National Laboratory, Argonne, IL. 
18. Delucchi, M. A. (2003), “A Lifecycle Emissions Model (LEM): Lifecycle Emissions From Transportation Fuels, Motor Vehicles, Transportation Modes, Electricity Use, Heating and Cooking Fuels, and Materials," Institute of Transportation Studies, University of California at Davis.

19. Kang D., Aneja, V. P., Das, M., and Seila, R. (2004), "Measurements of Air-Surface Exchange Rates of Volatile Organic Compounds," International Journal of Environment and Pollution, 22(5): 547-562.

20. EIA (2005), “Annual Energy Review 2004,” DOE/EIA-0384(2004), Energy Information Administration, Washington D.C.

21. He, D., Wang M. Q. (2000), "Contribution Feedstock and Fuel Transportation to Total Fuel-Cycle Energy Use and Emissions," SAE Paper No. 2000-01-2976, Presented at International Fuels \& Lubricants Meeting \& Exposition, Baltimore, MD, October.

22. Vojtisek-Lom, M., Cobb, J. T. (1997), "Vehicle Mass Emissions Measurement Using a Portable 5-Gas Exhaust Analyzer and Engine Computer Data," In Proceedings of Emission Inventory, Planning for the Future, Air \& Waste Management Association, Pittsburgh, PA.

23. Cullen, A. C., Frey H. C. (1999), Probabilistic Techniques in Exposure Assessment, Plenum Press: NY, Chapters 3-5.

24. Morgan, M. G., Henrion, M., (1990), Uncertainty: A Guide to Dealing with Uncertainty in Quantitative Risk and Policy Analysis, Cambridge University Press: NY.

25. Sonnemann, G. W., Schuhmacher, M., Castells, F. (2003), "Uncertainty Assessment by a Monte Carlo Simulation in a Life Cycle Inventory of Electricity Produced by a Waste Incinerator," Journal of Cleaner Production, 11(3): 279-292.

26. Lo, S.-C., Ma, H.-W., Lo, S.-L. (2005), "Quantifying and Reducing Uncertainty in Life Cycle Assessment Using the Bayesian Monte Carlo Method," Science of the Total Environment, 340(1-3): 23-33.

27. GM, LBST, bp, ExxonMobil, Shell (2002), "Well-to-Wheel Analysis of Energy Use and Greenhouse Gas Emissions of Advanced Fuel/Vehicle Systems - A European Study," GM European Well-to-Wheel Study, Prepared by L-B-Systemtechnik GmbH, Ottobrunn, Germany, September.

28. Abdel-Aziz, A., Frey, H. C. (2003), "Quantification of Hourly Variability in $\mathrm{NO}_{\mathrm{x}}$ Emissions for Baseload Coal-Fired Power Plants," Journal of the Air \& Waste Management Association, 53(11):1401-1411.

29. Frey H. C., Li S. (2003), "Methods for Quantifying Variability and Uncertainty in AP-42 Emission Factors: Case Studies for Natural Gas-Fueled Engines," Journal of the Air \& Waste Management Association, 53(12):1436-1447.

30. USDA (2002), "2002 Census of Agriculture - State Data," National Agricultural Statistics Service, U.S. Department of Agriculture, Washington D.C. 
Table 1. Characteristics of Tested Vehicles

\begin{tabular}{|c|c|c|c|c|c|c|c|c|c|}
\hline \multirow[b]{2}{*}{ Vehicle ID $^{1}$} & \multicolumn{4}{|c|}{ Chassis Characteristics } & \multicolumn{5}{|c|}{ Engine Characteristics } \\
\hline & Manufacturer & Year & Model $^{2}$ & $\begin{array}{l}\text { GVW } \\
\text { (lbs) }\end{array}$ & Tier & $\begin{array}{l}\text { Displacement } \\
\text { (liter) }\end{array}$ & Cylinders & Horsepower & $\begin{array}{c}\text { Cumulative Engine } \\
\text { Operating Hours }\end{array}$ \\
\hline BH1 & CATERPILLAR & 2004 & $420 \mathrm{D}$ & 22,000 & 2 & 4.0 & 4 & 97 & 78 \\
\hline $\mathrm{BH} 2$ & $\mathrm{JCB}$ & 1997 & 215 & 16,540 & 0 & 4.2 & 4 & 90 & 11,528 \\
\hline $\mathrm{BH} 3$ & JCB & 2001 & $2.15 \mathrm{E}-01$ & 16,540 & 1 & 4.2 & 4 & 90 & 2,792 \\
\hline $\mathrm{BH} 4$ & CASE & 1999 & 590SL & 19,578 & 1 & 3.9 & 4 & 99 & 3,874 \\
\hline BH5 & CATERPILLAR & 2004 & $420 \mathrm{D}$ & 22,000 & 2 & 4.0 & 4 & 97 & 740 \\
\hline FL1 & HYUNDAI & 2002 & HL740-TM3 & 29,000 & 1 & 5.9 & 6 & 130 & 3,645 \\
\hline FL2 & HYUNDAI & 2002 & HL740-TM3 & 29,000 & 1 & 5.9 & 6 & 130 & 9,345 \\
\hline FL3 & CASE & 2002 & 621B XT & 28,000 & 1 & 5.9 & 6 & 126 & 3,569 \\
\hline FL4 & HYUNDAI & 2005 & HL740-TM7 & 29,000 & 2 & 5.9 & 6 & 133 & 446 \\
\hline MG1 & VOLVO & 2001 & G720VHP & 37,000 & 1 & 8.27 & 6 & 195 & 4,367 \\
\hline MG2 & VOLVO & 2004 & G720B & 37,000 & 2 & 7.1 & 6 & 195 & 841 \\
\hline MG3 & VOLVO & 2001 & G720VHP & 37,000 & 1 & 8.27 & 6 & 195 & 3,044 \\
\hline MG4 & DRESSER & 1990 & 850 & 37,000 & 0 & 8.27 & 6 & 167 & 440 \\
\hline MG5 & CHAMPION & 1993 & G720 & 37,000 & 0 & 8.27 & 6 & 160 & 4,554 \\
\hline
\end{tabular}

$\mathrm{BH}=$ Backhoe

$\mathrm{FL}=$ Front-End Loader

MG $=$ Motor Grader

2 All tested vehicles are turbocharged. 
Table 2. Scenarios Included in Life Cycle Inventory Case Studies

\begin{tabular}{|c|l|l|l|}
\hline Scenario & \multicolumn{1}{|c|}{ Fuel Cycle } & \multicolumn{1}{|c|}{ Vehicle Emissions Data } & Descriptive Label \\
\hline 1 & Petroleum Diesel & In-Use Measurement & Diesel \\
\hline 2 & Pre-NSPS Soyoil Plant & In-Use Measurement & Pre-NSPS, In-Use \\
\hline 3 & Pre-NSPS Soyoil Plant & Engine Dynamometer & Pre-NSPS, Engine \\
\hline 4 & Pre-NSPS Soyoil Plant & Chassis Dynamometer & Pre-NSPS, Chassis \\
\hline 5 & NSPS Soyoil Plant & In-Use Measurement & NSPS, In-Use \\
\hline 6 & NSPS Soyoil Plant & Engine Dynamometer & NSPS, Engine \\
\hline 7 & NSPS Soyoil Plant & Chassis Dynamometer & NSPS, Chassis \\
\hline
\end{tabular}


Table 3. Examples of Best Estimates and Uncertainty Assumptions for Key Inputs for Front-End Loader 1

\begin{tabular}{|c|c|c|c|c|c|}
\hline \multicolumn{3}{|c|}{ Petroleum Diesel Life Cycle Inventory } & \multicolumn{3}{|c|}{ B20 Biodiesel Life Cycle Inventory } \\
\hline $\begin{array}{l}\text { Description } \\
\text { and units }\end{array}$ & $\begin{array}{c}\text { Best } \\
\text { Estimate }\end{array}$ & $\begin{array}{l}\text { Distribution and } \\
\text { parameters }^{\text {a }}\end{array}$ & $\begin{array}{l}\text { Description and } \\
\text { units }^{\text {a }}\end{array}$ & $\begin{array}{l}\text { Best } \\
\text { Estimate }\end{array}$ & $\begin{array}{l}\text { Distribution and } \\
\text { parameters }^{\text {a }}\end{array}$ \\
\hline $\begin{array}{l}\text { Crude Oil } \\
\text { Recovery } \\
\text { Efficiency, \% }\end{array}$ & $97.7^{\mathrm{c}}$ & Т:96.0-99.0 (98.0) & $\begin{array}{l}\text { Soybean Use; } \\
\text { soybean use per } \\
\text { lb. of soyoil } \\
\text { throughput }\end{array}$ & $5.9^{\mathrm{c}}$ & $\mathrm{N}: 5.3-6.5$ \\
\hline $\begin{array}{l}\text { Refining } \\
\text { Efficiency }\end{array}$ & $89.0^{\mathrm{c}}$ & N: $88.0-90.0$ & $\begin{array}{l}\text { Soyoil Use; } \\
\text { soyoil use per lb } \\
\text { of biodiesel } \\
\text { throughput }\end{array}$ & $1.04^{\mathrm{c}}$ & N: 5.74-6.06 \\
\hline $\begin{array}{l}\text { Tailpipe HC } \\
\text { Emission, } \\
\text { g/gal D.E. }\end{array}$ & $18^{\mathrm{d}}$ & $\mathrm{N}: 17.1-18.9$ & $\begin{array}{l}\text { Tailpipe HC } \\
\text { Emission, g/gal } \\
\text { D.E. }{ }^{\text {b }}\end{array}$ & $7.5^{\mathrm{d}}$ & $\mathrm{N}: 7.1-7.9$ \\
\hline $\begin{array}{l}\text { Tailpipe CO } \\
\text { Emission, } \\
\text { g/gal D.E. }{ }^{b}\end{array}$ & $16.3^{\mathrm{d}}$ & $\mathrm{N}: 15.0-17.6$ & $\begin{array}{l}\text { Tailpipe CO } \\
\text { Emission, g/gal } \\
\text { D.E. }^{\mathrm{b}}\end{array}$ & $8.7^{\mathrm{d}}$ & $\mathrm{N}: 8.0-9.4$ \\
\hline $\begin{array}{l}\text { Tailpipe } \mathrm{NO}_{\mathrm{x}} \\
\text { Emission, } \\
\text { g/gal D.E. }\end{array}$ & $110^{\mathrm{d}}$ & $\mathrm{N}: 106.7-113.3$ & $\begin{array}{l}\text { Tailpipe } \mathrm{NO}_{\mathrm{x}} \\
\text { Emission, g/gal } \\
\text { D.E. }{ }^{\mathrm{b}}\end{array}$ & $113^{\mathrm{d}}$ & N: $109.6-116.4$ \\
\hline $\begin{array}{l}\text { Tailpipe PM } \\
\text { Emission, } \\
\text { g/gal D.E. }\end{array}$ & $6.9^{\mathrm{d}}$ & $\mathrm{N}: 6.6-7.3$ & $\begin{array}{l}\text { Tailpipe PM } \\
\text { Emission, g/gal } \\
\text { D.E. }{ }^{\mathrm{b}}\end{array}$ & $5.3^{\mathrm{d}}$ & $\mathrm{N}: 5.0-5.6$ \\
\hline \multicolumn{6}{|c|}{$\begin{array}{l}\mathrm{T}=\text { triangular distribution; } \mathrm{N}=\text { normal distribution. For the triangular distribution, the range of } \\
\text { minimum to maximum is shown with the mode given in parentheses. For normal distributions, the } 2.5^{\text {th }} \\
\text { and } 97.5^{\text {th }} \text { percentile are given. }\end{array}$} \\
\hline \multicolumn{6}{|c|}{$\begin{array}{l}\text { Selected cases are converted to a per gallon of petroleum diesel equivalent basis. Per gallon diesel } \\
\text { equivalent (D.E.) on an energy basis is } 128,500 \mathrm{Btu} / \mathrm{gallon} \text {. }\end{array}$} \\
\hline \multicolumn{6}{|c|}{ Based on GREET 1.6 Model. } \\
\hline Based reference & ,7). & & & & \\
\hline
\end{tabular}


Table 4. Average Percentage Difference ${ }^{a}(\%)$ of Life Cycle Inventory Emissions for B20 versus Petroleum Diesel per Gallon of Diesel Equivalent

\begin{tabular}{|c|c|c|c|c|c|}
\hline & \multirow[t]{2}{*}{ Scenario } & \multicolumn{4}{|c|}{$\begin{array}{c}\text { Average Percentage Difference (\%) of LCI Emissions for B20 versus } \\
\text { Petroleum Diesel LCI } \\
(95 \% \text { Probability Range })^{b}\end{array}$} \\
\hline & & $\mathrm{NO}_{\mathrm{x}}$ & PM & $\mathrm{HC}$ & $\mathrm{CO}$ \\
\hline (2) & $\begin{array}{l}\text { Pre-NSPS, } \\
\text { In-Use }\end{array}$ & $\begin{array}{c}\mathbf{+ 2 . 5} \\
(+1.5 \text { to }+4.2)\end{array}$ & $\begin{array}{c}\mathbf{- 1 4 . 0} \\
(-15.7 \text { to }-12.2)\end{array}$ & $\begin{array}{c}\mathbf{+ 4 . 3} \\
(+2.1 \text { to }+6.5)\end{array}$ & $\begin{array}{c}\mathbf{- 5 . 2} \\
(-8.4 \text { to }-2.0)\end{array}$ \\
\hline (3) & $\begin{array}{l}\text { Pre-NSPS, } \\
\text { Engine }\end{array}$ & $\begin{array}{c}\mathbf{+ 5 . 2} \\
(+4.3 \text { to }+6.0)\end{array}$ & $\begin{array}{c}-7.5 \\
(-8.5 \text { to }-6.6)\end{array}$ & $\begin{array}{c}+7.6 \\
(+5.9 \text { to }+9.3)\end{array}$ & $\begin{array}{c}\mathbf{+ 3 . 3} \\
(+0.6 \text { to }+5.5)\end{array}$ \\
\hline (4) & $\begin{array}{l}\text { Pre-NSPS, } \\
\text { Chassis }\end{array}$ & $\begin{array}{c}\mathbf{+ 3 . 9} \\
(+3.0 \text { to }+4.6)\end{array}$ & $\begin{array}{c}\mathbf{- 1 3 . 5} \\
(-14.4 \text { to }-12.7)\end{array}$ & $\begin{array}{c}\mathbf{+ 1 6 . 3} \\
(+14.5 \text { to }+18.1)\end{array}$ & $\begin{array}{c}\mathbf{- 2 . 3} \\
(-4.9 \text { to }-0.3)\end{array}$ \\
\hline (5) & $\begin{array}{l}\text { NSPS, } \\
\text { In-Use }\end{array}$ & $\begin{array}{c}\mathbf{+ 1 . 7} \\
(+0.9 \text { to }+3.4)\end{array}$ & $\begin{array}{c}\mathbf{- 1 4 . 3} \\
(-15.7 \text { to }-12.6)\end{array}$ & $\begin{array}{c}\mathbf{- 9 . 9} \\
(-12.6 \text { to }-6.7)\end{array}$ & $\begin{array}{c}\mathbf{- 1 0 . 7} \\
(-13.9 \text { to }-6.8)\end{array}$ \\
\hline (6) & $\begin{array}{l}\text { NSPS, } \\
\text { Engine }\end{array}$ & $\begin{array}{c}\mathbf{+ 4 . 5} \\
(+3.8 \text { to }+5.3)\end{array}$ & $\begin{array}{c}-\mathbf{- 7 . 8} \\
(-8.2 \text { to }-7.2)\end{array}$ & $\begin{array}{c}\mathbf{- 6 . 6} \\
(-8.9 \text { to }-3.8)\end{array}$ & $\begin{array}{c}\mathbf{- 2 . 1} \\
(-4.6 \text { to }+0.8)\end{array}$ \\
\hline (7) & $\begin{array}{l}\text { NSPS, } \\
\text { Chassis }\end{array}$ & $\begin{array}{c}\mathbf{+ 3 . 2} \\
(+2.5 \text { to }+3.9)\end{array}$ & $\begin{array}{c}\mathbf{- 1 3 . 7} \\
(-14.2 \text { to }-13.2)\end{array}$ & $\begin{array}{c}\mathbf{- 2 . 1} \\
(-4.4 \text { to }+0.8)\end{array}$ & $\begin{array}{c}-\mathbf{- 7 . 8} \\
(-10.2 \text { to }-4.8)\end{array}$ \\
\hline & Iverage & +3.5 & -11.8 & +1.6 & -4.1 \\
\hline
\end{tabular}


Table 5. Proportion of Vehicle Tailpipe Emissions to Total Life Cycle Inventory Emissions Based on Vehicle Types and Engine Tier (NCSU In-Use Measurement data)

\begin{tabular}{|c|c|c|c|c|c|c|c|c|}
\hline \multirow{2}{*}{$\begin{array}{c}\text { Vehicle } \\
\text { Type }\end{array}$} & \multirow{2}{*}{ Fuel Cycle ${ }^{a}$} & \multirow{2}{*}{$\begin{array}{c}\text { Engine } \\
\text { Tier }\end{array}$} & \multicolumn{6}{|c|}{ Tailpipe Emissions as a Percentage of Life Cycle Inventory } \\
\hline & & & $\mathrm{NO}_{\mathrm{x}}$ & PM & $\mathrm{HC}$ & $\mathrm{CO}$ & $\mathrm{CO}_{2}$ & Fossil $\mathrm{CO}_{2}$ \\
\hline \multirow{9}{*}{ Backhoe } & \multirow{3}{*}{$\begin{array}{l}\text { Petroleum } \\
\text { Diesel }\end{array}$} & Tier 0 & 95.6 & 98.6 & 93.6 & 98.4 & 84.6 & 84.6 \\
\hline & & Tier 1 & 95.5 & 97.7 & 89.9 & 96.7 & 84.6 & 84.6 \\
\hline & & Tier 2 & 95.4 & 94.7 & 90.9 & 88.8 & 84.6 & 84.6 \\
\hline & \multirow{3}{*}{$\begin{array}{l}\text { B20 } \\
\text { Pre-NSPS }\end{array}$} & Tier 0 & 92.7 & 98.0 & 75.7 & 94.8 & 79.4 & 72.9 \\
\hline & & Tier 1 & 91.6 & 96.2 & 63.9 & 90.3 & 79.4 & 72.9 \\
\hline & & Tier 2 & 92.0 & 90.7 & 54.6 & 70.6 & 79.4 & 72.9 \\
\hline & \multirow{3}{*}{ B20 NSPS } & Tier 0 & 93.4 & 98.1 & 83.9 & 96.0 & 80.9 & 73.5 \\
\hline & & Tier 1 & 92.4 & 96.3 & 74.5 & 92.6 & 80.9 & 73.5 \\
\hline & & Tier 2 & 92.7 & 91.1 & 66.4 & 76.2 & 80.9 & 73.5 \\
\hline \multirow{6}{*}{$\begin{array}{l}\text { Front-End } \\
\text { Loader }\end{array}$} & \multirow{2}{*}{$\begin{array}{l}\text { Petroleum } \\
\text { Diesel }\end{array}$} & Tier 1 & 96.2 & 95.5 & 93.7 & 90.9 & 84.6 & 84.6 \\
\hline & & Tier 2 & 95.2 & 90.7 & 84.3 & 91.1 & 84.6 & 84.6 \\
\hline & \multirow{2}{*}{$\begin{array}{l}\text { B20 } \\
\text { Pre-NSPS }\end{array}$} & Tier 1 & 93.4 & 92.0 & 66.1 & 69.7 & 79.4 & 72.9 \\
\hline & & Tier 2 & 91.7 & 86.6 & 53.2 & 73.5 & 79.4 & 72.9 \\
\hline & \multirow{2}{*}{ B20 NSPS } & Tier 1 & 94.0 & 92.3 & 76.6 & 75.6 & 80.9 & 73.5 \\
\hline & & Tier 2 & 92.4 & 87.1 & 65.6 & 78.8 & 80.9 & 73.5 \\
\hline \multirow{12}{*}{$\begin{array}{l}\text { Motor } \\
\text { Grader }\end{array}$} & \multirow{4}{*}{$\begin{array}{l}\text { Petroleum } \\
\text { Diesel }\end{array}$} & Tier 0 & 96.5 & 98.0 & 94.0 & 95.7 & 84.6 & 84.6 \\
\hline & & Tier 1 & 95.8 & 95.1 & 94.0 & 91.2 & 84.6 & 84.6 \\
\hline & & Tier 2 & 95.3 & 89.2 & 92.0 & 89.1 & 84.6 & 84.6 \\
\hline & & Tier 3 & 93.4 & 83.7 & 85.6 & 86.0 & 84.6 & 84.6 \\
\hline & \multirow{4}{*}{$\begin{array}{l}\text { B20 } \\
\text { Pre-NSPS }\end{array}$} & Tier 0 & 93.9 & 96.7 & 77.1 & 86.5 & 79.4 & 72.9 \\
\hline & & Tier 1 & 92.7 & 92.0 & 74.6 & 77.6 & 79.4 & 72.9 \\
\hline & & Tier 2 & 92.3 & 82.7 & 66.5 & 73.1 & 79.4 & 72.9 \\
\hline & & Tier 3 & 89.1 & 75.8 & 53.2 & 57.6 & 79.4 & 72.9 \\
\hline & \multirow{4}{*}{ B20 NSPS } & Tier 0 & 94.4 & 96.8 & 84.9 & 89.6 & 80.9 & 73.5 \\
\hline & & Tier 1 & 93.3 & 92.3 & 83.0 & 82.2 & 80.9 & 73.5 \\
\hline & & Tier 2 & 93.0 & 83.3 & 76.9 & 78.5 & 80.9 & 73.5 \\
\hline & & Tier 3 & 90.0 & 76.5 & 65.6 & 64.6 & 80.9 & 73.5 \\
\hline
\end{tabular}

$\mathrm{PD}=\quad$ Petroleum diesel fuel cycle;

B20 Pre-NSPS = B20 fuel cycle with Pre-NSPS soyoil plants; and

B20 NSPS $=\quad$ B20 fuel cycle with NSPS soyoil plant. 


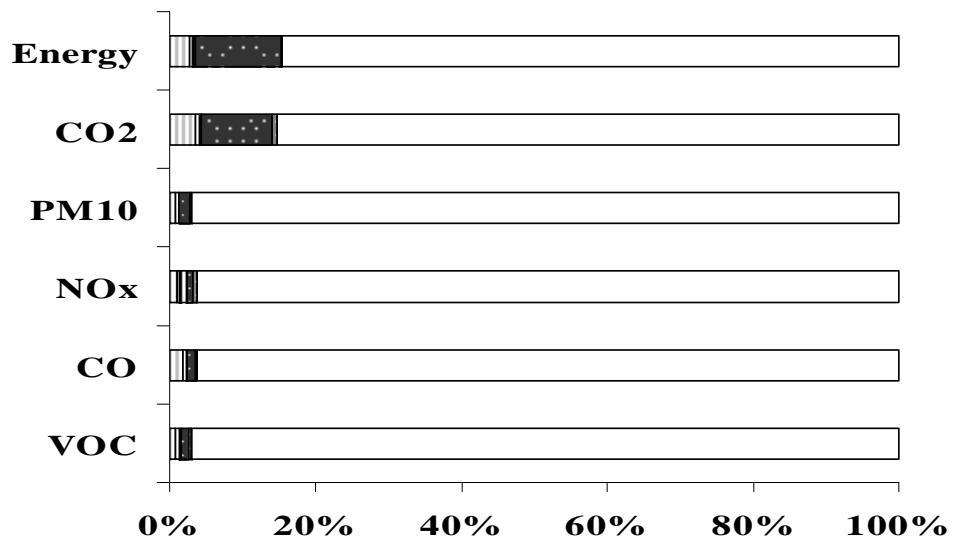

Scenario 1: Petroleum Diesel LCI

$\square$ Crude Oil Recovery III Crude Oil Transport

Crude Oil Refining

$\square$ Diesel Transport

$\square$ Vehicle Operation

Cumulative Percent of Total Life Cycle Values

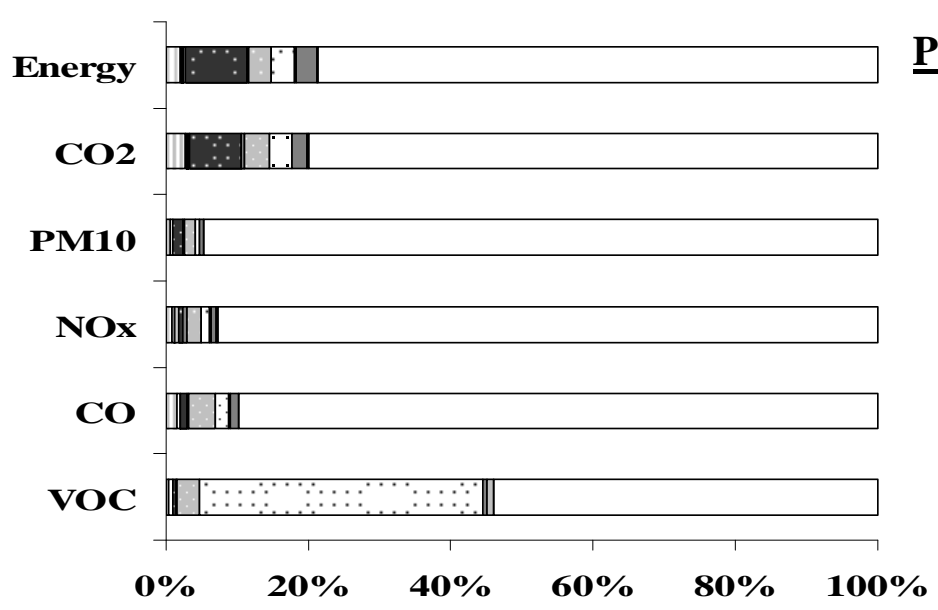

Scenario 2: B20 LCI Pre-NSPS Soyoil Plant, In-Use

Crude Oil Recovery

Ill Crude Oil Transport

- Crude Oil Refining

- Diesel Transport

$\square$ Soybean Farming

$\checkmark$ Soyoil Plant

$\square$ Soyoil Transport

$\square$ Biodiesel Plant

$\square$ Biodiesel Transport

$\square$ Vehicle Operation

Cumulative Percent of Total Life Cycle Values

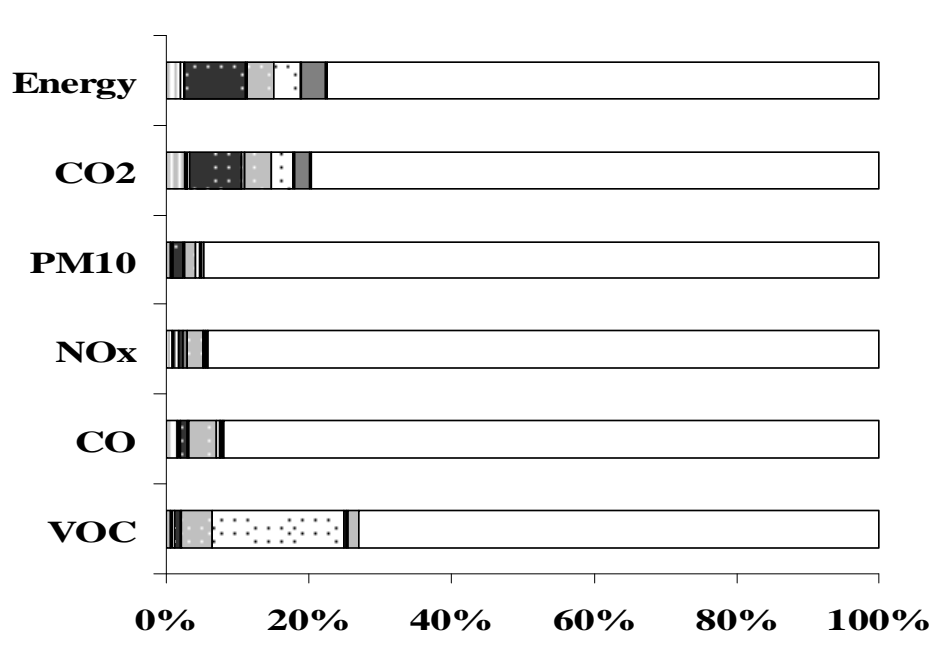

Scenario 5: B20 LCI NSPS

Soyoil Plant, In-Use

$\square$ Crude Oil Recovery

血 Crude Oil Transport

$\square$ Crude Oil Refining

$\square$ Diesel Transport

$\square$ Soybean Farming

$\square$ Soyoil Plant

$\square$ Soyoil Transport

$\square$ Biodiesel Plant

$\square$ Biodiesel Transport

$\square$ Vehicle Operation

Cumulative Percent of Total Life Cycle Values

Figure 1. Example of Life Cycle Inventory Results for Scenarios 1, 2, and 5 


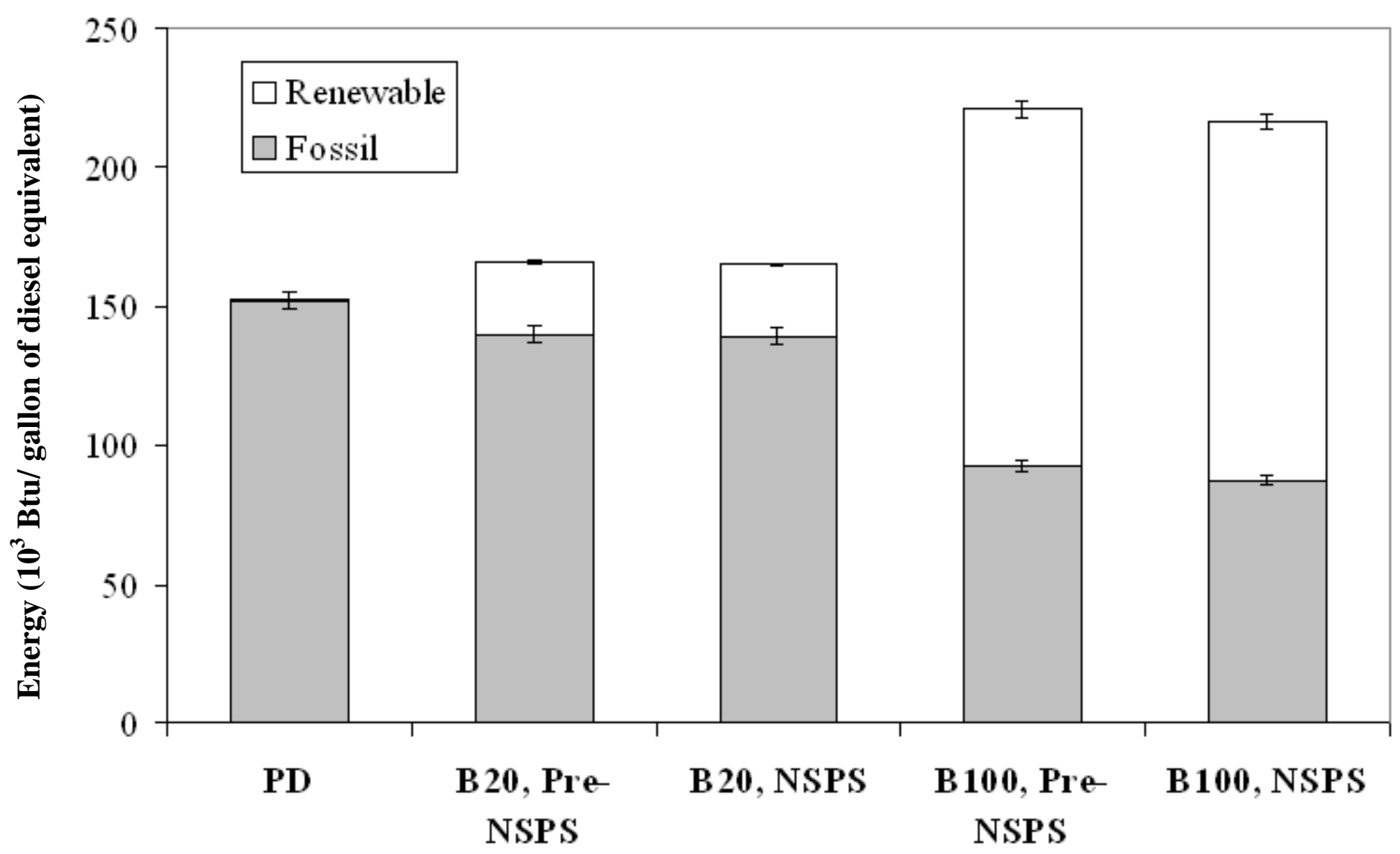

Note: $95 \%$ confidence intervals on the mean value are indicated.

Figure 2. Fossil and Total Energy Consumption for Petroleum Diesel, B20, and B100 Life Cycle Inventory per Gallon of Petroleum Diesel Equivalent 


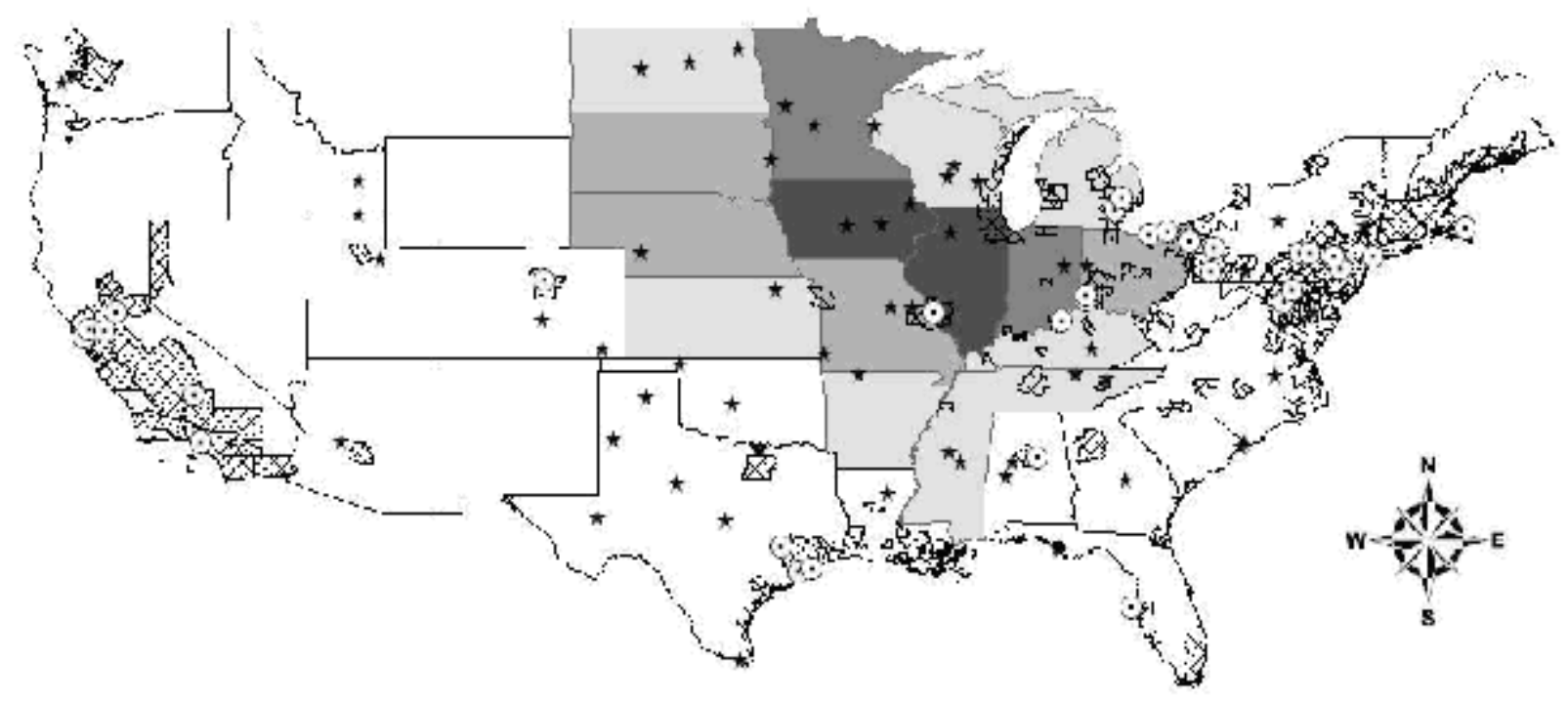

Soybean Yield

(million bushel per year)

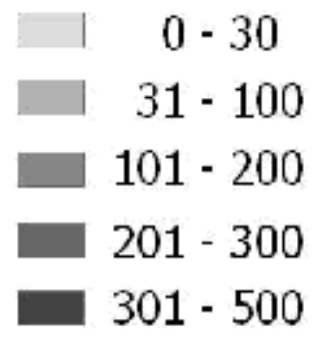

\section{Biodiesel Plant in Ozone Nonattainment Area \\ * Biodiesel Plant elsewhere \\ xo Ozone Nonattainment Area}

Figure 3. Geographic distribution of Soybean Yield, Biodiesel Plants and Air Quality Non-attainment Area in the U.S. 

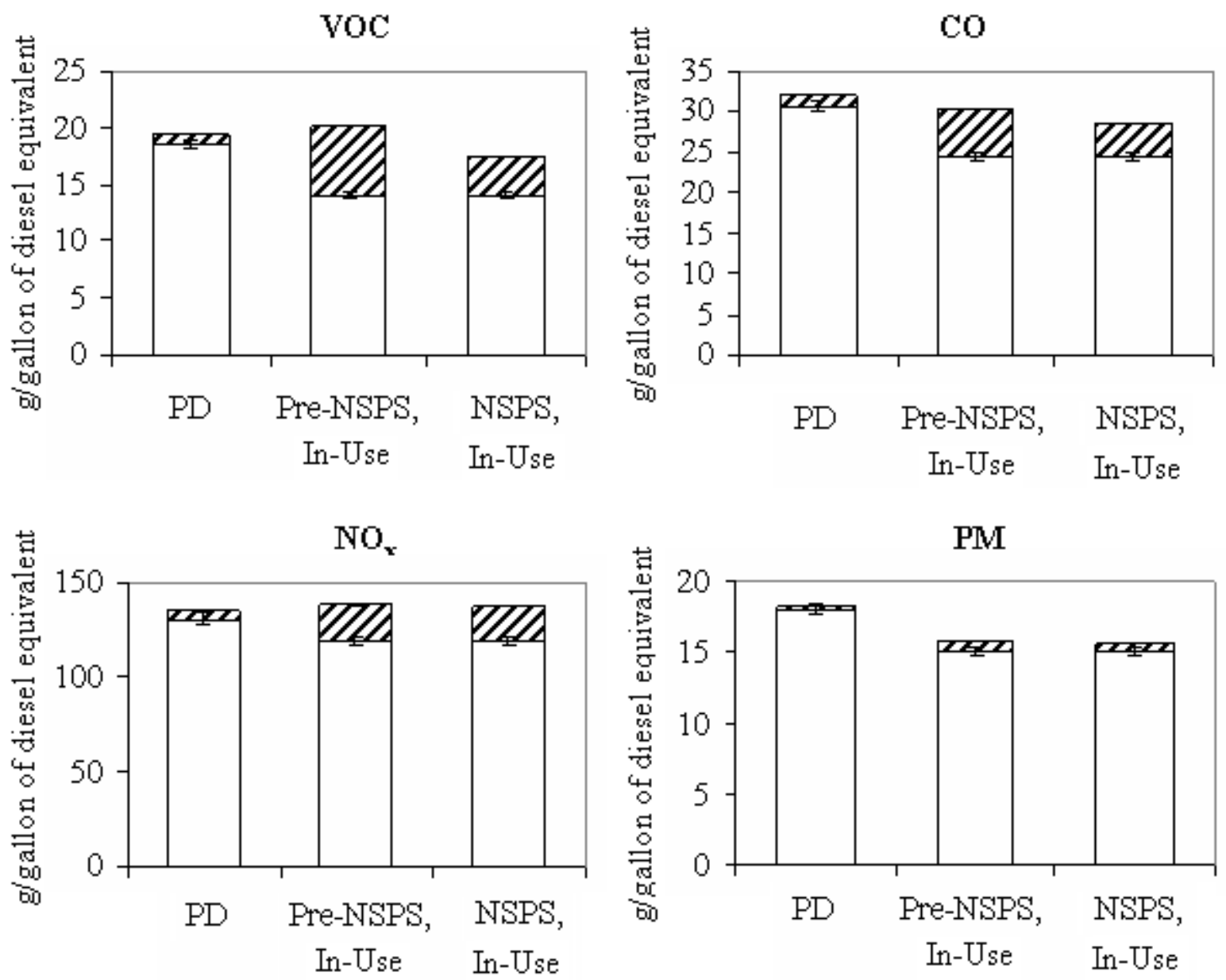

Predominately Local Urban Emissions (Local fuel transport and vehicle tailpipe emissions)

Predominately Rural Emissions (Other stages of life cycle emissions)

Figure 4. Comparison of Typical Local Urban and Total Emissions Based on Life Cycle Inventory Scenario 1,2 , and 5 